\title{
Ocular Adnexal Lymphoma
}

National Cancer Institute

\section{Source}

National Cancer Institute. Ocular Adnexal Lymphoma. NCI Thesaurus. Code C88145.

A non-Hodgkin lymphoma arising from the conjunctiva, lacrimal gland, lacrimal drainage apparatus, eyelids, or other orbital tissues around the eye. The vast majority of cases are extranodal marginal zone lymphomas of mucosa-associated lymphoid tissue, however, other histologic types of lymphomas can originate from ocular adnexal tissues, including rare cases of NK/T-cell lymphomas of nasal type. 